\title{
APPLIED COMPUTATIONAL LATIN DIALECTOLOGY: PRELIMINARY RESULTS FROM THE CONVENTUS PACENSIS (SOUTH PORTUGAL)
}

\author{
CONTINUITY AND LINGUISTIC INNOVATION*
}

\begin{abstract}
Summary: The aim of this paper is to present the preliminary results of my research on the Vulgar Latin in the Lusitania province. The research is being conducted within the framework of the computational project LLDB and concerns the regional diversification of Latin. By providing support graphics, this software allows the visualisation of data according to the different linguistic levels as well as their statistical distribution in diachronic perspective.
\end{abstract}

Key words: regional diversification of Latin, Latin dialectology, Latin epigraphy, vulgar Latin, Latin of Hispania, Lusitania

\section{INTRODUCTION}

Throughout my collaboration with the project "Computerized Historical Linguistic Database of Latin Inscriptions of the Imperial Age” (LLDB: http://lldb.elte.hu/), ${ }^{1}$ I will present some of the preliminary results of my research on the Vulgar Latin in the

* This article was written within the framework of the project FFI2015-68571-P sponsored by the Spanish Government, as well as of my collaboration with the project OTKA (Hungarian Scientific Research Fund) No. K 108399 entitled "Computerized Historical Linguistic Database of Latin Inscriptions of the Imperial Age" and of the project entitled "Lendület ('Momentum') Research Group for Computational Latin Dialectology" (Research Institute for Linguistics of the Hungarian Academy of Sciences). I would like to thank Prof. Béla Adamik for his support and Gloria Geretto for improving the English text of this paper.

${ }^{1}$ ADAMIK, B.: Im memoriam József Herman: von der Late Latin Database bis zur Computerized Historical Linguistic Database of Latin Inscriptions of the Imperial Age. Acta Ant. Hung. 49 (2009) 11-22. 
province of Lusitania, ${ }^{2}$ the main area of my research. ${ }^{3}$ In particular, I will focus on the conventus Pacensis, which is the Southern part of Lusitania and of the modern state of Portugal (see picture 1).

By using inscriptions as my primary source of linguistic data, ${ }^{4}$ as suggested by Herman's methodology, ${ }^{5}$ I will attempt to outline the most relevant linguistic patterns identified in this region, their distribution and continuity from the Pagan to the early Christian age. ${ }^{6}$ To facilitate the quantitative analysis of the data collected and its graphical representation, the software provided by LLDB will be used.

\section{THE SELECTED PROVINCE}

The provincia Hispania Ulterior Lusitania and the Baetica were established by Augustus, who divided into two parts the former province of Hispania Ulterior, which was founded in 197 BC alongside the Hispania Citerior. From that moment on, the Citerior became known as Tarraconensis. Later on, Gallaecia and Asturias, which initially belonged to Lusitania, became part of the Tarraconensis. From the $5^{\text {th }}$ to the $8^{\text {th }}$ century AD, the province fell under the rule of the Visigoths, who invaded and governed the Peninsula until the Arabs' invasion. ${ }^{7}$

\footnotetext{
${ }^{2}$ I continued the data collection begun by Réka Visontai, who recorded part of the materials cited in this paper.

${ }^{3}$ The aim of the $\mathrm{PhD}$ research project which I am currently working on is the partial update of the book by CARNOY, A.: Le latin d'Espagne d'après les inscriptions. Étude linguistique. Bruxelles 1906².

${ }^{4}$ As outlined in the "Guidelines for data collection" of LLDB, all data should be intended as "linguistic phenomena that can be isolated at text level (in terms of surface manifestation, such phenomena can be phonetic [orthographic], morphological, syntactic, lexicographical, or lexico-semantic) and that deviate from what is called the classical norm" (http://lldb.elte.hu/admin/doc_guidelines.php). The "norm" is intended as the linguistic corpus documented in the texts of the classical authors.

${ }^{5}$ HeRMAN, J.: Differenze territoriali nel latino parlato dell'Italia tardo-imperiale: un contributo preliminare. In HERMAN, J. - MARINETTI, A. (eds.): La preistoria dell'italiano. Atti della Tavola Rotonda di Linguistica Storica. Università Ca' Foscari di Venezia 11-13 giugno 1998. Tübingen 2000, 123-135. Some scholars do not consider inscriptions as the main source for Vulgar Latin, see ADAMS, J. N.: The Regional Diversification of Latin. 200 BC - 600 AD. Cambridge 2007, passim. With reference to this topic, see ADAMIK, B.: In Search of the Regional Diversification of Latin: Some Methodological Consideration in employing the inscriptional evidence. In BIVILLE, FR. et al. (eds.): Latin vulgaire - latin tardif IX. Actes du IXe colloque international sur le latin vulgaire et tardif, Lyon, 6 - 9 septembre 2009. Lyon 2012, 123-139.

${ }^{6}$ I have collected my data from the following books and papers: ENCARNAÇãO, J.: Inscrições romanas do conventus Pacensis. Subsídios para o estudo da romanização. Coimbra 1984; ENCARNAÇão, J.: Inscrições romanas do conventus Pacensis. Aditamento. Trabalhos de Arqueologia do Sul. Évora 1 (1986) 99-109; Alves DiAS, M. M. - GASPAR, C.: Catalogo das inscrições Paleocristãs do Território Português. Lisboa 2006; EnCARNAÇão, J.: IRCP. 25 anos depois. RPA 11 (2008) 215-230. I also used the review Ficheiro Epigráfico (Universidade de Lisboa. 1982-) until the issue 134 (April 2016).

${ }^{7}$ For a more complete overview on the history of Lusitania, see SALINAS DE FRÍAS, M. - EDMONDSON, J.: La provincia de Lusitania. In NAVARRo CABALLERO, M. - RAMírEZ SÁdABA, J. L. (eds.): Atlas antroponímico de la Lusitania romana. Mérida-Bordeaux 2003, 51-56.
} 


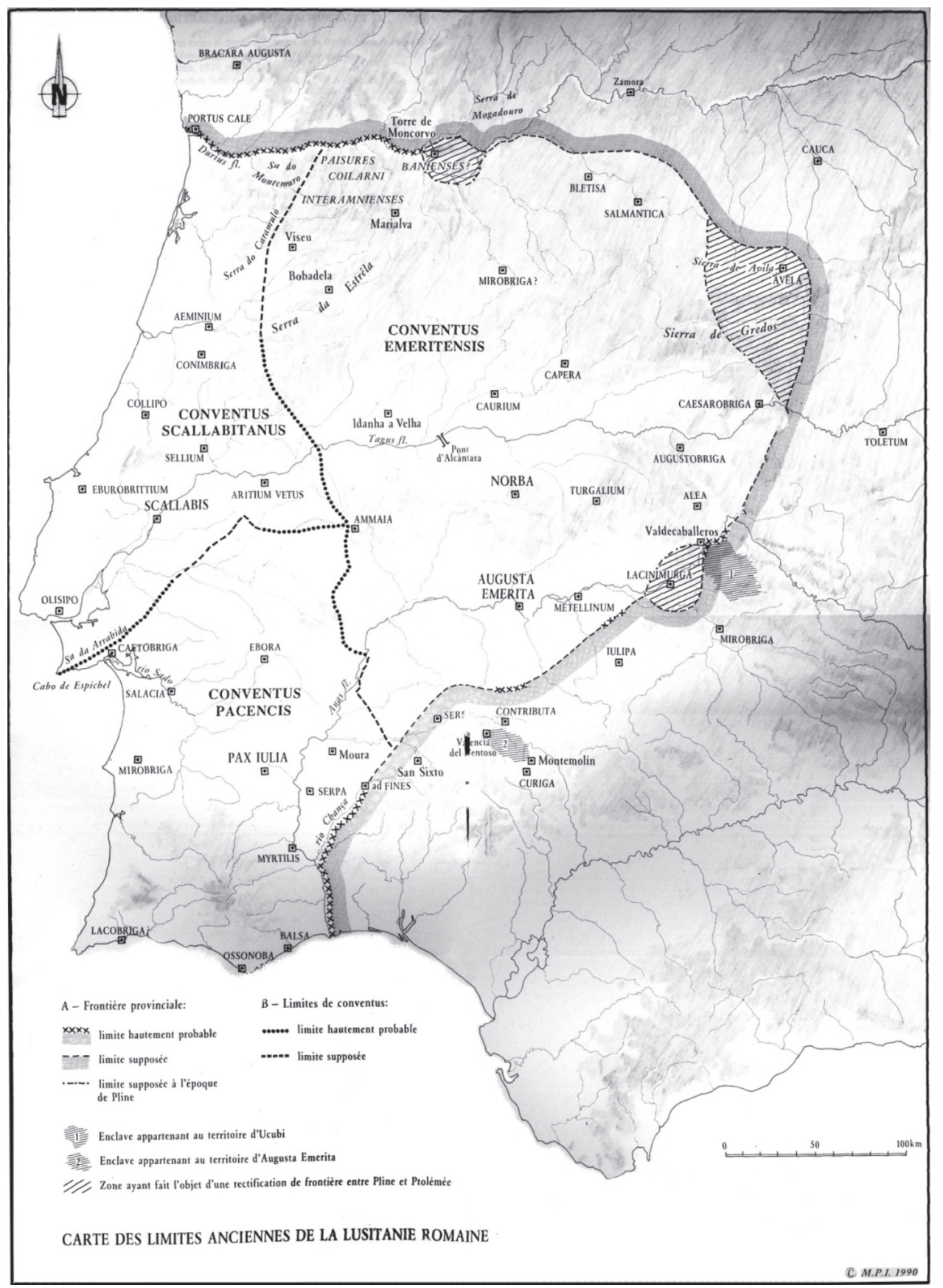

Picture 1. The province of Lusitania and the conventus Pacensis

Les villes de la Lusitanie romaine. Hiérarchie et territoire. Table ronde internatioinale du CNRS (Talence, le 8-9 décembre 1988). Paris 1990 
Lusitania was named after the Lusitani, ${ }^{8}$ the original inhabitants of the region. Information about this population has been found in some inscriptions written in the so-called "Lusitanian language" and which date back to the $2^{\text {nd }}$ century AD, ${ }^{9}$ as well as in other inscriptions", which combine indigenous theonimy of no Latin morphology with classical Latin. ${ }^{10}$ Indeed, Lusitanian onomastics has been documented in the Latin epigraphy of the province until the $3^{\text {rd }}$ cent. AD. ${ }^{11}$

Augustus further divided the Hispania province into conventus iuridici. Three of these belonged to Lusitania (see picture 1), and were named after their capital cities: Emeritensis (from Emerita Augusta, modern Mérida, in Spain), Scallabitanus (from Scallabis, modern Santarém) and Pacensis (from Pax Iulia, modern Beja, both in Portugal). ${ }^{12}$

\section{DELIMITATION OF THE CORPUS}

In my corpus all the variants of local onomastics (person, place and names of gods) ${ }^{13}$ have been excluded, since these have only been acknowledged through the Latin epigraphy and, as such, their original spelling cannot be authenticated. It follows that their adaptation to Latin morphology cannot be evaluated for dialectological studies on Latin.

Furthermore, some of the features denoting the group of phonology have also been omitted. Specifically, according to Herman, phenomena which share only an orthographical meaning should be omitted. These data are particularly useful when examining the alphabetization level of a specific society, however their relevance in terms of dialectology is scarce. ${ }^{14}$ Some of the writings that seem to deviate from the "norm" may derive from the local cultural tradition and/or from the knowledge of the "orthographic rules" of the Latin language in a particular place or by a single text author $^{15}$. This occurs for example when the grapheme $\mathrm{X}$ is replaced by ICS or by one of its less phonologically relevant variants (i.e., XS, SX, SC, etc.).

There are other phenomena then, which are not particularly significant from a linguistic point of view and that are therefore generally omitted in dialectological stud-

\footnotetext{
${ }^{8}$ Vallejo Ruiz, J. M.: Hacia una nueva definición del lusitano. Paleohispanica 13 (2013) 274.

${ }^{9}$ VALLEJO RUIZ: Hacia una nueva definición (n. 8) 284-286.

${ }^{10}$ VAlLejo RuIZ, J. M.: Viejas y nuevas cuestiones de lengua en el occidente peninsular: el lusitano y la onomástica. Paleohispanica 9 (2009) 275.

${ }^{11}$ Vallejo Ruiz, J M.: Antroponimia indigena de la Lusitania romana. Universidad del País Vasco 2005, 82 .

${ }^{12}$ To establish the geographical limits of the considered conventus, the book by NAVARRO CABALLERO - RAMíREZ SÁDABA (n. 7) has been used here as a reference. By doing so, Aritium Vetus has been excluded here, although it can be found in this conventus in ENCARNAÇÃO: Inscrições (n. 6). See Picture 1.

${ }^{13}$ A good example is represented by the numerous variants of the god's name Endovellicus, also referred to as: Endovolicus, Indovellicus, Enbolicus, etc. (cfr. ENCARNAÇÃO: Inscrições [n. 6], nr. 482-565).

${ }^{14}$ HeRmAN, J.: Aspects de la différenciation territoriale du latin sous l'Empire (1965). In HERMAN, J. : Du latin aux langues romanes. Études de linguistique historique. Réun. par S. KISS. Tübingen 1990, $14-16$.

${ }^{15}$ It is hard to speak about "norm" (n. 4) and "orthographic rules" in the case of Latin. On this topic, see DESBORDES, F.: Idées romaines sur l'écriture. Lille 1990, 161-171.
} 
ies. ${ }^{16}$ One example is the reduction of $a e$ into /ę/, which has been documented since the $1^{\text {st }}$ century $\mathrm{BC},{ }^{17}$ or the loss of the aspirated $h$ in Latin words, which is also an ancient phenomenon. ${ }^{18}$ Another example is the frequent contraction of the double $i$, $o$ and $u$ (i.e., filis pro filiis, cors pro cohors, perpetum pro perpetuum, etc.) as well as the degemination of consonants, which is also a common evolution of the majority of Romance languages. ${ }^{19}$ The confusion between I, V and Y in Greek terms is mainly due to the subsequent introduction of this letter -originally present in the Greek alphabetand the newly formed sound /ü/ in Latin. ${ }^{20}$ Similarly, the aspiration of the unvoiced occlusive consonants $c, p, t$ (as $c h, p h, t h$ ) and of the vibrant $r$ (as $r h$ ) was been influenced by a common trend with the introduction of Greek elements in Latin vocabulary. ${ }^{21}$ In a similar way, the introduction of the new grapheme $\mathrm{G}^{22}$ caused an oscillation of the letters $\mathrm{C} / \mathrm{G}$. Lastly, the fall of the ending letter $-m$ before a vowel is irrelevant in terms of versification, and it is likely to indicate that the letter was not pronounced. ${ }^{23}$ In light of these considerations, it can be argued that the dialectological value of these phenomena is not relevant.

This paper seeks to present a general overview of the linguistic patterns of the conventus Pacensis. Specifically, given the complexity and limitation of the current debate on these issues, special focus will be given to those phenomema denoting a particular dialectological valence. Only the confusion $A E \sim E$ will be excluded from this analysis, since it frequently appears throughout the entire body of inscriptions of the Roman Empire. ${ }^{24}$ With regard to the consonantal system, the loss of aspiration as well as the pure orthographical variants such as the various alternative forms of $X$ with no phonological meaning (i.e., ICS, XS, SX, etc. but not S, SS, CX, which suggest instead the sound /s/ or /s:/) will be omitted. Additionally, the oscillations $P H \sim F$

\footnotetext{
${ }^{16}$ Herman, J.: La différentiation territoriale du latin et la formation des langues romanes (1985). In HERMAN, J.: Du latin aux langues romanes (n. 14) 79-82.

${ }^{17}$ Herman, J.: Vulgar Latin. Transl. by Roger Wright. Pennsylvania University Park 2000, 31. Vineis argues that the monophthongization of $a e$ into $e$ and of $a u$ into $o$ occurred in the spoken language between the $3^{\text {rd }}$ and the $2^{\text {nd }}$ centuries BC, see VINEIS, E.: Problemi di ricostruzione della fonologia del latino volgare. In VINEIS, E. (a cura di): Latino volgare, latino medioevale, lingue romanze. Atti del Convegno della Società Italiana di Glottologia. Perugia, 28 e 29 marzo 1982. Pisa 1984, 54-56. On this topic, see also Coleman, R.: The Monophthongization of /ae/ and the Vulgar Latin Vowel System. Transactions of the Philological Society 70/1 (1971) 175-191.

18 VÄ̈̈NÄNEN, V.: Introduction au latin vulgaire. Paris 1967, 57-58.

19 VÄÄNÄNEN (n. 18) 60-62; HERMAN: Vulgar Latin (n. 17) 48.

${ }^{20}$ Moralejo, J. L.: Notas sobre la grafía Y en inscripciones latinas. Cuadernos de Filología Clásica 4 (1972) 169.

${ }^{21}$ With reference to this topic, see MORALEJO, J. L.: Notación de la aspiración consonántica en el latín de la República. Bologna 1968.

${ }^{22}$ Cf. JEKL, A.: Cambiamenti fonetici del latino nella provincia della Scythia Minor. In International Conference on Linguistics and Classical Languages (LCL), February 17-19, 2011, Roma, Italia - forthcoming; and TANTIMONACO, S.: Ultra Anam flumen. Apuntes de alfabetización en la Lusitania meridional. In Carbonell Manils, J. - Gimeno PaCual, H. (eds.): A Baete ad fluvium Anum. Cultura epigráfica en la Bética Occidental y territorios fronterizos. Homenaje al profesor José Luis Moralejo Álvarez. Alcalá de Henares 2016, 243-264.

${ }^{23}$ HERMAN: Vulgar Latin (n. 17) 49-50.

${ }^{24}$ HeRman: Vulgar Latin (n. 17) 126.
} 
(almost homophone) and $C \sim Q \sim K$ will also be excluded from this analysis since their variations may depend on the individual or regional use. Lastly, throughout the section Nominalia, the adjective pientissiumus (a substitute for piissimus) will not be used since it is a common feature in epigraphy and therefore it is not particularly relevant from a dialectological perspective (although it is not cited in literary sources and thus generally recorded in LLDB).

Two specific periods will be taken into consideration: an early stage $\left(1^{\text {st }}-3^{\text {rd }}\right.$ centuries) and a later one ( $4^{\text {th }}-8^{\text {th }}$ centuries), ${ }^{25}$ while some graphics will be used to support the visualisation of the evolution of the language over the timeframe. The analysis will also address two linguistic levels: the Phonologica (comprising Vocalismus and Consonantismus) and the Morphosyntactica (comprising Nominalia and Syntactica). With reference to Morphosyntactica, only Nominalia will be investigated in depth and special emphasis will be given to the diachronic evolution of the nominal case system. ${ }^{26}$

\section{CHRONOLOGICAL DISTRIBUTION}

Inscriptions from the conventus Pacensis date between the $1^{\text {st }}$ and the $8^{\text {th }}$ century AD. Most data available date back to the $2^{\text {nd }}$ or to the $3^{\text {rd }}$ century AD (43\% in total), a period of prolific production of epigraphy. Nevertheless, a significant quantity of data can also be found in the $1^{\text {st }}$ century $(15 \%)$. Few of these are inscriptions dating back to the $4^{\text {th }}$ and to the $5^{\text {th }}$ century (5\% in total). The quantity of data seems to increase again throughout the $6^{\text {th }}$ and $7^{\text {th }}$ century (29\% in total) and gradually decrease later on (only $1 \%$ is recorded throughout the $8^{\text {th }}$ century). A small percentage of data (7\%) has not been dated yet, however, in this paper, only dated inscriptions are taken into consideration.

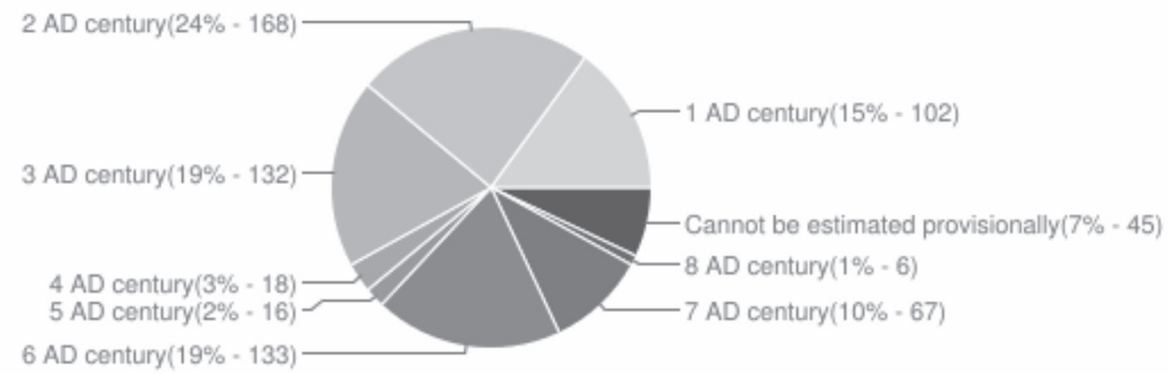

${ }^{25}$ See HERMAN: La différentiation territoriale (n. 16) 63; ADAMIK, B.: In Search of the Regional Diversification of Latin: Changes of the Declension System According to the Inscriptons. In MoLINELLI, P. - Cuzzolin, P. - FedriAni, C. (eds.) : Latin vulgaire - Latin tardif X. Actes du X $X^{\mathrm{e}}$ colloque international sur le latin vulgaire et tardif. Bergamo, 5-9 septembre 2012. Bergamo 2014, 645 and also MoLinelli, P. - Cuzzolin, P. - FEDriani, C. (eds.): The frequency of syncope in the Latin of the Empire: a statistical and dialectological study based on the analysis of inscriptions. In POCETTI, P. (ed.): Latinitatis Rationes. Descriptive and Historical Accounts for the Latin Language. Roma 2016, 3-21.

${ }^{26}$ The labels herein cited refer to those adopted in the LLDB database. I have conducted an indepth study of the so-called "errores non grammatici" of this territory, see TANTIMONACO (n. 22). 
The majority of inscriptions analysed here, which have been recorded since the $5^{\text {th }}$ century, are Paleo-Christian. Interestingly then, many of these inscriptions, mostly epitaphs, indicate the year of production which is expressed by the "aera" system. ${ }^{27}$ This feature has allowed us to accurately record the inscriptions in chronological order.

The graphics above show a general decrease in linguistic phenomena throughout the $4^{\text {th }}$ and $5^{\text {th }}$ century; according to a substantial change in the epigraphic habit of the later times. Similarly, the decrease recorded throughout the $8^{\text {th }}$ century may be the result of the Arab conquest of Hispania (see par. 2). The overall number of recorded data is 687 .

\section{LINGUISTIC LEVELS}

The primary source of information pertaining to the early inscriptions comes from Phonologica, which includes some of those features discussed above (see par. 3). This field contains $72 \%$ of the overall number of data recorded to date, while the section Morphosyntactica includes the remaining $28 \%$.

\section{Early inscriptions}

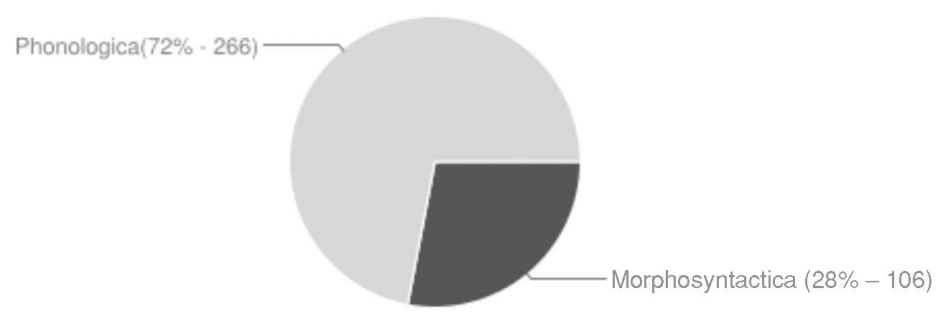

Specifically, of the overall number of phonological data, $41 \%$ belongs to Consonantismus and $30 \%$ to Vocalismus. The phenomena recorded as Nominalia are $16 \%$ while those belonging to Syntactica are $13 \%$.

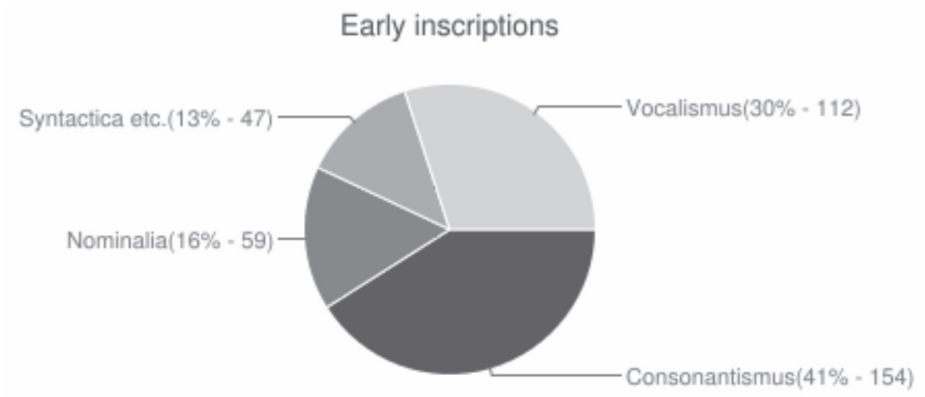

${ }^{27}$ See Handley, M. A.: Tiempo e identidad: la datación por la era en las inscripciones de la España tradorromana y visigoda. Iberia 2 (1999) 191-202. 
Later on, Phonologica became the most prolific field with $81 \%$ of inscriptions, compared to only $19 \%$ in Morphosyntactica.

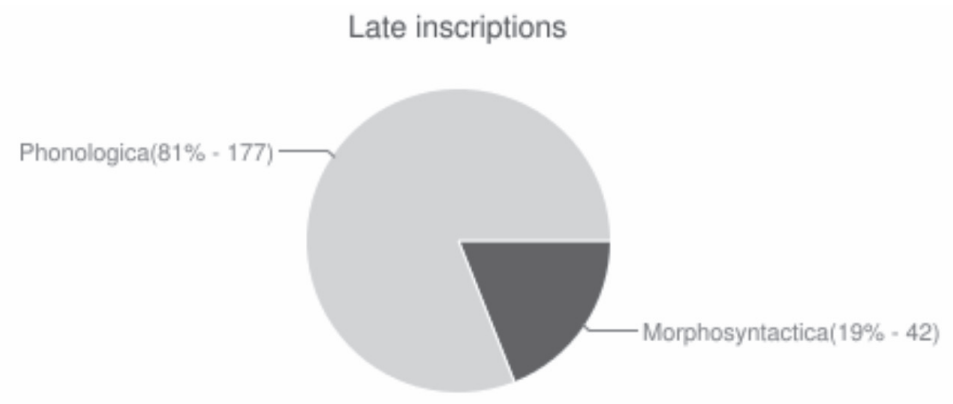

Of the overall number of data, $56 \%$ belongs to Vocalismus, $26 \%$ to Consonantismus, $12 \%$ to Nominalia and $6 \%$ to Syntactica.

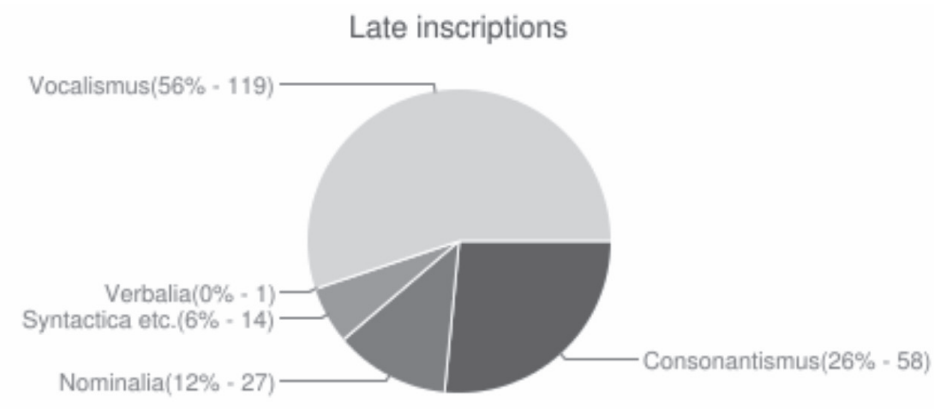

Compared to the earlier centuries, the later period offers a higher volume of vocalic features $(30>56 \%)$ and a smaller number of consonantic phenomena $(41>26 \%)$; the first group almost doubled while the second group seems to have halved. In other words, this area shows a significant activity of both vowel and consonant systems, as well as a tendency towards vocalic variations. ${ }^{28}$

\section{PHONOLOGICA}

\subsection{Vocalismus}

The analysis of data referring to the vocalic pattern of early inscriptions shows a common phenomenon in Vulgar Latin, namely the merger of $/ \bar{e} /$ and $/ \breve{l} /$ with $/ e /$, as well as the fusion of $/ \bar{o} /$ and $/ \breve{u} /$ into $/ o /$, according to the diachronic evolution of the vocalic system in classical Latin:

\footnotetext{
${ }^{28}$ See HERMAN: Vulgar Latin (n. 17) 128.
} 


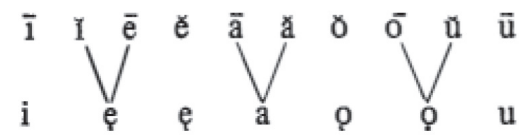

As a result of this, it is possible to identify three forms of $\bar{e}$, stressed $\bar{e}$ and stressed ae diphthong which become $i$ (i.e., IRINAEI pro Irenei; MINS(IBVS) pro mensibus; $A E O D O L(V M)$ pro idolum ${ }^{29}$ ) and five inverted cases of short $\breve{l}$ which become $e$ (RELEGIONE pro religione; EPOLITA pro Hypolita; HELAERIANVS pro Hilarianus; MERSINAE pro Myrsinae; POMPELI[ANVS,A] pro Pompilianus ${ }^{30}$ ). These examples suggest that, in spoken language, one single phoneme was used to produce two sounds, $\mid \bar{e} /$ and $/ \breve{l} / .^{31}$

Furthermore, some cases of merger $\breve{e} \sim \bar{l}$ have also been recorded (i.e., four cases: AVINTINA pro Aventina; HIRINIANA pro Herenniana, twice; $H S$ I pro hic situs est ${ }^{32}$ ). This may indicate a wider confusion between the sounds $/ e /$ and $/ i /$, particularly in unstressed syllables. ${ }^{33}$ On the other hand, the transformation of $e+$ vowel into $i$ (2 data: MISOLIO pro mausoleum; CONIACTIA pro conlactia ${ }^{34}$ ), of ie into e (FACENDVM pro faciendum ${ }^{35}$ ) or of ae into ai (3 cases) seems to stem from the confusion between the unstressed $e$ and $i$, and a semivowel $j$, when found in hiatus. ${ }^{36}$

A similar case can be observed in the merger $o \sim u$. Some examples show $\bar{o}$ becoming $\breve{u}$ (EX VOTV, CVM SIGNV, EX RESPONSV $\left.{ }^{37}\right)$, or stressed or unstressed $\breve{o}$ becoming $u\left(C O L O M B(A), M V N I M E N T V M^{38}\right)$ and viceversa $u>o$ (CLAVOM pro clavum, SI SERVOS ERIT pro si servus erit, ANORO pro annorum ${ }^{39}$ ).

Another common feature in the vocalic system is the syncope, alongside its inverted phenomenon of epenthesis/anaptyxis. These represent $16 \%$ of the overall number of vocalic data available.

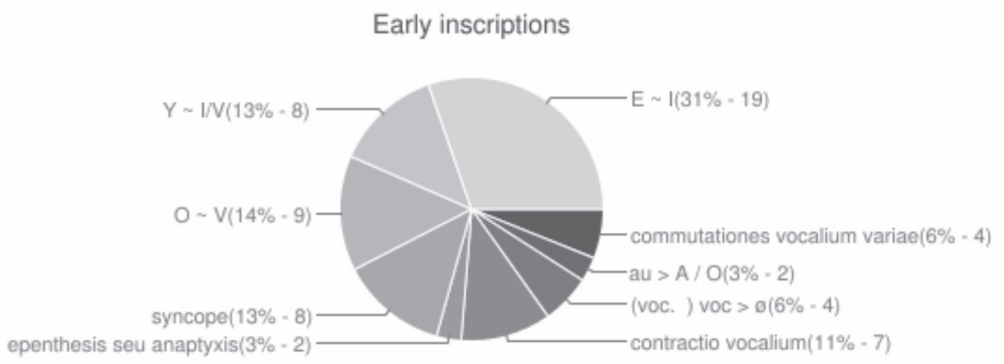

${ }^{29}$ LLDB-28028, 30224 and 29884.

${ }^{30}$ LLDB-16417, 17416, 30078, 42627 and 42671.

${ }^{31}$ HERMAN: Vulgar Latin (n. 17) 31.

${ }^{32}$ LLDB-16962, 16963, 29529 and 32056.

${ }^{33}$ Cfr. HeRMAN: Vulgar Latin (n. 17) 129.

${ }^{34}$ LLDB-16960 and 30091.

35 LLDB-17150.

${ }^{36}$ HERMAN: Vulgar Latin (n. 17) 35.

${ }^{37}$ LLDB-16956, 29552 and 29561.

${ }^{38}$ LLDB-42436 and 16948.

${ }^{39}$ LLDB-16977, 16986, 17318, 17322, 17328 and 42312. The examples CLAVOM pro clavum and SERVOS pro servus are considered archaisms, see HERMAN, J.: Essai sur la latinité du littorale adriatique à l'époque de l'Empire (1971). In HERMAN: Du latin aux langues romanes (n. 14) 138-139. 
Throughout the later period, the confusions between $e \sim i$ and $o \sim u$ remain particularly relevant from a linguistic point of view, and increases sensibly (respectively: $31>32 \%$ and $14>16 \%$ ). On the other hand, the number of monophtongization $a u>a$ seems to increase. An example of this is the word AVGVSTVS which refers to the eighth month of the year in dates (four times ${ }^{40}$ ). The semplification of the $a u$ dipthong into simple $a$, which is otherwise very stable in Romance, is generally observed in the initial syllable, when the following one starts with another $u$, as a process of dissimilitation, (i.e., the Italian verb ascoltare from Latin auscultare and similarly the Portugese noun agosto from Latin augustus ${ }^{41}$ ). While this process of monophtongization cannot be recorded until much later, the transformation $a u>o$ in words such as olla, oricla, pollulus etc., can be found in many classical texts. ${ }^{42}$

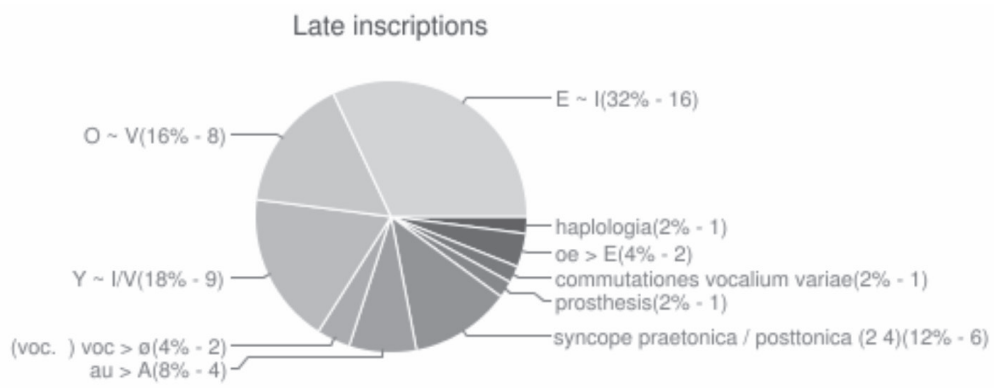

On the other hand, the syncope decreases throughout our corpus $(13>12 \%)$. In a recent study on this phenomenon based on inscriptional evidence, ${ }^{43}$ Adamik observed a lack of congruence between the overall view provided by the inscriptions and the reality of Romance languages. Indeed, the general tendency documented by these inscriptions seems to coincide with a decrease in the use of the syncope. To date, it is generally acknowledged that this process does not occur in Romance languages as regularly as a real phonetic rule; ${ }^{44}$ however, it is undoubtedly characteristic of the Western Romance, which tends to preserve the paroxytone variants instead of the proparoxytone (i.e. the Spanish noun doce / Portugese doze vs. Italian dodici, from Latin duodecim ${ }^{45}$ ). Nevertheless, with regard to the increasing frequency of the syncope, our epigraphic materials do not show the same tendency. Specifically, the provisional results of the study conducted in the entire province of Lusitania show a gradual decrease in this phenomenon, from $11 \%$ to $7 \%$ (from twenty-nine to twelve cases). This aspect seems to suggest that

${ }^{40}$ LLDB-29728, 29911, 29944 and 31773.

${ }^{41}$ VÄÄNÄNEN (n. 18) 40. See also VINEIS (n. 17) and FiSCHER, I.: Remarques sur le traitement de la diphtongue au en latin vulgaire. Revue roumaine de linguistique 13/5 (1968) 417-420.

${ }^{42}$ See FISCHER (n. 41$) 417$.

${ }^{43}$ ADAMIK (n. 25).

${ }^{44}$ VÄÄNÄNEN (n. 18) 41. Also see ANDERSON, J. M.: A Study of Syncope in Vulgar Latin. Word 21 (1965) 70-85 and HERMAN, J.: L'évolution du latin dans les provinces de l'Empire. Problèmes et perspectives (1984). In HERMAN: Du latin aux langues romanes (n. 14) 56-59.

${ }^{45}$ VÄÄNÄNEN (n. 18) 42. 
the syncope appeared in Hispania only much later and following a gradual decrease. ${ }^{46}$ However, more in-depth research is needed to validate these data.

\subsection{Consonantismus}

In addition to the degemination and its hypercorrected forms (30\%), the most common feature of the early inscriptions in Consonantismus is the fall of the final letters (24\%). This includes the fall of the final $-m$ (18 data), of the final $-s$ (3 data) and of the final $-t$ (2 data), which occur very frequently in Vulgar Latin. ${ }^{47}$ When analysing this kind of phenomena, it is important to consider their potential morphosyntactical value, since the loss of a final $-m$ may result into an ablative with an ending $-u$ from an original accusative with ending - $u m$ and so on $^{48}$. The same thing can be said for the unnecessary addition of a final $-m$, which occurs four times in our corpus (PR[O] SALVTEM, PRO VERNACLAM, EX IVENTVTEM, CVM QVAM ${ }^{49}$ ).

Devoicing is another example of well-established phenomenon (12\%), particularly when $\mathrm{G}$ turns into $\mathrm{C}$ ( 4 cases) and $\mathrm{D}$ becomes $\mathrm{T}$ ( 3 cases). The opposite trend of lenition is indeed a very common feature in Western Romance. ${ }^{50}$ Some examples of this trend can be observed in terms such as Spanish amigo / Portuguese amigo from Latin amicus. It follows that, more evidence would certainly help confirm the trend in this territory, however this is not the case (nevertheless, LLDB database does reveal some additional case of lenition recorded in the province of Lusitania).

The simplification of the nexus - $n s$ - into simple $-s$ - and its hypercorrected forms is very common in Vulgar Latin and well known in our territory (10\%). ${ }^{51}$

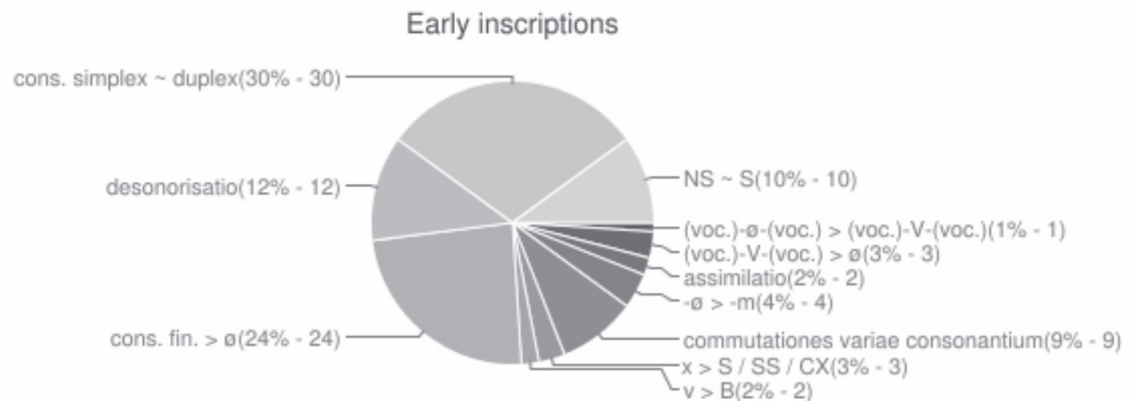

${ }^{46}$ Syncope depends on the variability of accents, see ADAMIK, B.: A study on the dialectology of Vulgar Latin vocalic mergers: the interaction between confusion of vowel quality, syncope and accent. In Latin Vulgaire - Latin Tardif XI: $11^{\text {th }}$ International Conference on Late and Vulgar Latin, Oviedo 1-4 September 2014 - forthcoming.

${ }^{47}$ HERMAN: La différentiation territoriale (n. 16) 81-84; HERMAN: Vulgar Latin (n. 17) 39-42.

${ }^{48}$ HERMAN: Vulgar Latin (n. 17) 42. This is precisely the reason why the final $-d$ and $-t$ are generally more stable in words than the final $-m$, in order to preserve the clarity of the verbal system and of the language (VÄÄNÄNEN [n.18] 71). This fact also explains why, in my study, the same phenomenon which can be interpreted in two different ways appears in both Phonologica and Nominalia.

${ }^{49}$ LLDB-16993, 29676, 30185 and 41852.

${ }^{50}$ Posner, R.: The Romance Languages. Cambridge 1996, 289.

51 VÄÄNÄNEN (n. 18) 66-67. 
Later periods show the same typology of phenomena in the consonantal pattern. Duplication or simplification of consonants are still the most documented examples (32\%), together with the loss of final letters (33\%), especially $-m$ ( 7 cases) and $-s$ (3 cases). The simplification of $-n s$ - into $-s-(6 \%)$ is also documented. Devoicing cases have not been documented, although some cases of B $\sim \mathrm{V}$ confusion (13\%) have been reported. ${ }^{52}$

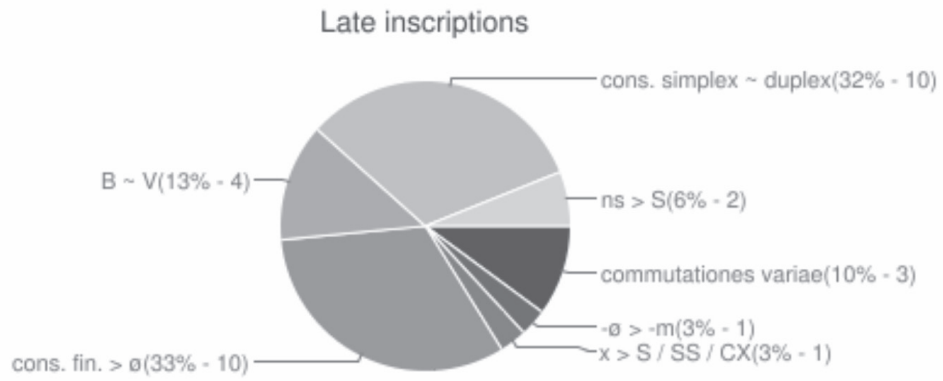

\section{MORPHOSYNTACTICA: NOMINALIA}

With regard to the nominal pattern, some instability can be observed in early times, particularly in the case system. The most recurring feature is the confusion between accusative and ablative: $46 \%$, reaching $57 \%$ if we include the confusion between the homograph nominative/ablative cases with the accusative, (e.g. STATVA... P(OSVERVNT) or ANIMA DO DONO ${ }^{53}$ ). Another widely reported phenomenon is the interchange between nominative and dative (14\%) as well as between genitive and ablative (11\%). The accusative is also used in place of the nominative in some examples $(5 \%$, which reaches $16 \%$ if we include the confusion nominative/ablative $\sim$ accusative mentioned above).

The other attested feature within the nominal system is the confusion between the IV and the II declension (5\%) which may correspond to the phonological evolution $\bar{o}>u$, as it is occurs to the ablative (see above, par. 6.1).

\section{Early inscriptions}

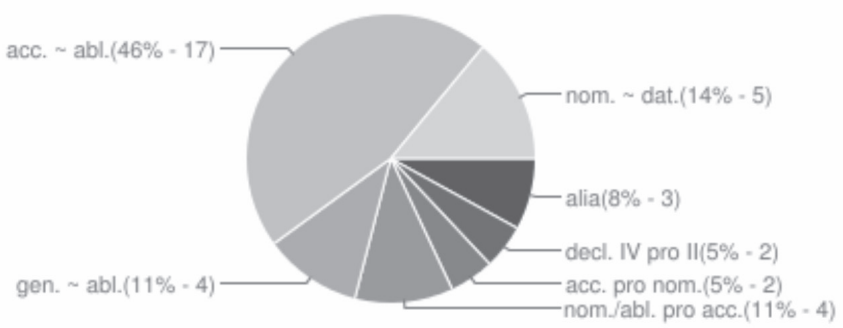

${ }^{52}$ With reference to this phenomenon, see ADAMIK in the present volume, pp. 11-33.

${ }^{53}$ LLDB-16966 and 31875. 
A further analysis of the nominal system in later times shows that the previous confusions have been levelled out by the predominant interchange between accusative and ablative, which represents $42 \%$ of data, if we include the confusion nominative/ ablative $\sim$ accusative $(24 \%+18 \%)$.

Furthermore, an example of merging genitive pro dative (EDIFICIVM...MARTIRVM QOR CONSTAT ESSE SACRATVM pro aedificium... martyrum quibus constat esse sacratum ${ }^{54}$ ) has also been observed. A review of the data collected in Lusitania shows several examples of this genitive $\sim$ dative interchange dating back to early periods: four cases (and two additional cases in late inscriptions). ${ }^{55}$ This fact is particularly interesting, since some scholars have suggested that the development of a one-case nominal system can already be recorded in much earlier times, with a premature fusion between nominative and accusative. Consequently, declensions is believed to have disappeared shortly after, as confirmed by the lack of examples of case system in the Western Romance, unlike the Eastern Romance which includes the isolated example of Rumanian. ${ }^{56}$ In fact, it is precisely in Dalmatia that Adamik has recorded the higher number of oscillations bewteen genitive and dative, which will disclose the future Vulgar Latin system of the Balkans. This is believed to be formed by two groups of cases: one comprising the nominative, accusative and ablative and the other including the dative and genitive. ${ }^{57}$ It follows that, confirming the presence of the genitive dative confusion in Lusitania since the early periods may be particularly useful to the study of the process of destructuration of the classical Latin declension system as well as to the development of the future Ibero-Romance system.

\begin{tabular}{|l|l|l|l|}
\hline Vulgar Latin Case-system & nominative & accusative-ablative & dative-genitive \\
\hline $\begin{array}{l}\text { 1. Gaul (Old French, } \\
\text { Old Occitan) }\end{array}$ & & \\
\hline $\begin{array}{l}\text { 2. Balkans } \\
\text { (Rumanian) }\end{array}$ & \\
\hline $\begin{array}{l}\text { 3. Africa (Hispania, Italia), } \\
\text { modern Romance }\end{array}$ & \\
\hline
\end{tabular}

Picture 2. Different regions of the Vulgar Latin declension system according to ADAMIK (n. 25) 658.

Similarly, the examples of genera permutata in later times $(28 \%$ of the overall number) reflect the crisis of the declension system, where masculine tends to predominate over femenine ( 3 times in our corpus) as well as over neutrum ( 2 times). ${ }^{58}$

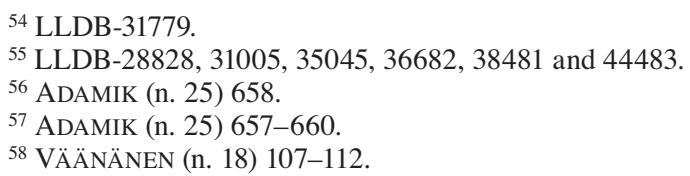




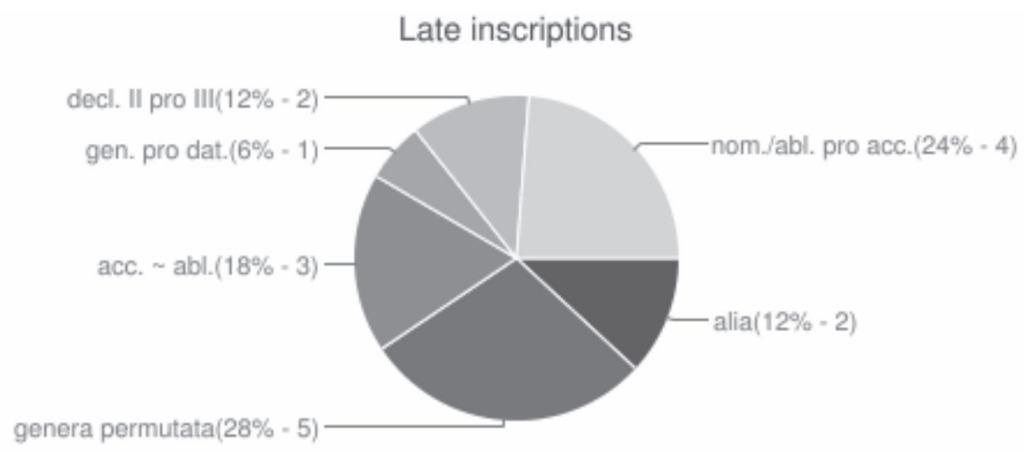

\section{CONCLUSIONS}

In this paper, I have presented the preliminary results of my research on the spoken Latin of Lusitania by focusing on the epigraphic materials of the conventus Pacensis. The tendencies that have emerged refer to the general Vulgar Latin system while a specific regularity of the language has also been observed in this region. In this corpus some hypotheses have been advanced; however, more research is required to validate or retract these arguments. The further development of the LLDB-project will allow a more in-depth exploration of the regional diversification of Latin as well as of the main processes of the Latin dialectology. Within this framework, the conclusions of my research on the Vulgar Latin in Lusitania aim to offer a more detailed overview of the linguistic patterns identified in this province and therefore contribute to the validation or retraction as well as further investigation of some of the features that have emerged so far in the conventus Pacensis. According to Herman's methodology, a further exploration of these features would provide the "dialectological profile" of this province..$^{59}$ Lastly, a comparative analysis of the results obtained in other territories of the Roman Empire will provide a better understanding of the dialectization process of the Latin language both in space and time.

Silvia Tantimonaco

Universitat de Barcelona

FI-DGR (2014) Fellowship / Grup de recerca consolidat LITTERA

silvia.tantimonaco@ub.edu

59 HeRman: Differenze territoriali (n. 5) 126. 